\title{
Developmental Neuropsychological Assessment
}

National Cancer Institute

\section{Source}

National Cancer Institute. Developmental Neuropsychological Assessment. NCI

Thesaurus. Code C95403.

A series of neurocog nitive tests for children from 3 to 16 years of age. NEPSY can be used for general, diagnostic, selective, or full assessment of neuropsychological development. (Copyright: Pearson Education, Inc; Marit Korkman, Ph.D., Ursula Kirk, Ph.D., and Sally Kemp, Ph.D., authors) 